\title{
THE TEXTURAL EFFECT OF Cu DOPING AND THE ELECTRONIC EFFECT OF Ti, Zr AND Ge DOPINGS UPON THE PHYSICAL PROPERTIES OF $\mathrm{IN}_{2} \mathrm{O}_{3}$ and Sn-DOPED IN $\mathrm{O}_{3}$ CERAMICS
}

\author{
S.J. WEN, G. CAMPET \\ Laboratoire de Chimie du Solide du CNRS, Université Bordeaux I, 351 Cours de la Libération, 33405 \\ Talence (France) \\ (Received June 14, 1992; in final form August 6, 1992)
}

\begin{abstract}
The electronic properties of $\mathrm{Cu}$-, Ti-, $\mathrm{Zr}$-, and Ge-doped $\mathrm{In}_{2} \mathrm{O}_{3}(\mathrm{IO})$ and ITO $\left(\mathrm{Sn}\right.$-doped $\left.\mathrm{In}_{2} \mathrm{O}_{3}\right)$ ceramics are investigated. We distinguish the different effect of $\mathrm{Cu}$ doping (so called the "textural effect") and of $\mathrm{Ti}, \mathrm{Zr}$ and $\mathrm{Ge}$ dopings (so called the "electronic effect") of IO and ITO ceramics. Indeed, Cu doping in IO and ITO enhances the ceramic density and thereby the conductivity due to an increase in the carrier mobility (grain boundary effect); the absorbance in the visible region is then lowered. Most interestingly for $\mathrm{Ti}$-, $\mathrm{Zr}$-, and Ge-doped samples, the increase of conductivity associated with an enlargement of the electron-mobility along with a decrease of the absorbance in the visible, account for the weak interactions occuring between the conduction-band electrons and the ionized donor centers.
\end{abstract}

\section{INTRODUCTION}

Simultaneous high electrical conductivity and transparency in the visible, occuring (i) for undoped but oxygen-deficient $\mathrm{In}_{2} \mathrm{O}_{3}$ (IO) films or (ii) for Sn-doped $\operatorname{In}_{2} \mathrm{O}_{3}$ (ITO) films, leads to interesting applications as transparent electrodes and heat mirrors. Hence, numerous researchers have characterized the electrical and optical parameters of such thin films $[1,2]$. However, with increasing sophistication of active and passive devices based on ITO thin films, there is still a need for enhancing both the conductivity and the transparency in the visible.

Therefore, an important question arises: "Can the conductivity and the transparency of ITO be improved by doping with appropriate elements?"

In order to thoroughly investigate the effect of doping of IO or ITO film on their electronic properties, it is worthwhile to study ceramics first. Indeed, the ratio of the doping element can be more easily modulated in ceramics than in thin films: Consequently its influence on the electronic properties can be more accurately investigated.

The films also have the same "disadvantages" as the ceramics, such as the relative small size of the grains, which can cause a drop in the carrier mobility (textural effect related to grain-boundary effect). For the above reported reasons, it is more judicious to solve this problem on ceramics first. 
Therefore, in the first part of this paper, we will report on the beneficial influence of $\mathrm{Cu}$ doping of IO and ITO ceramics on the density accounting for grain-percolation (the "textural effect") and correlate it to the electrical and optical properties. The choice of $\mathrm{Cu}$ doping element arises from a previous study on $\mathrm{Cu}$-doped $\mathrm{SnO}_{2}$ films [3].

In the second part of this paper, we will report on the direct influence of Ge, $\mathrm{Zr}$, Ti doping of IO and ITO on their properties (the "electronic effect"). We have indeed previously reported that Ge doping of IO and ITO samples, either in ceramic or film form, induces a significant enhancement of the carrier mobility and, thereby, of the optoelectronic properties [4, 5]. We will study here $\mathrm{Ti}$ or $\mathrm{Zr}$ doped $\mathrm{IO}$ and ITO ceramics. For sake of clarity this investigation will be carried out on the basis of a comparative study with Ge-doped ceramics.

Although the transport properties of polycrystalline ceramics differs from the intrinsic values obtained on single crystals, the relative values of the charge-carrier

TABLE I

The choice of the doping elements (IO doped samples)

\begin{tabular}{|c|c|c|c|c|}
\hline $\begin{array}{l}\text { Ceramic } \\
\text { symbolization }\end{array}$ & $\begin{array}{l}\text { Starting } \\
\text { materials } \\
\text { (99.999\% pure } \\
\text { Alpha prod.) }\end{array}$ & $\begin{array}{l}\text { Cationic } \\
\text { doping- } \\
\text { elements } \\
\text { present }\end{array}$ & $\begin{array}{l}\text { Formation of } \\
\text { cond. band } \\
\text { el., } \mathrm{e}^{-}[\mathrm{C} . \mathrm{B} .] \text { : } \\
\text { examples }\end{array}$ & $\begin{array}{l}\text { "Lewis acid } \\
\text { strength" of } \\
\text { the doping } \\
\text { elements [6] }\end{array}$ \\
\hline IO & $\operatorname{In}_{2} \mathrm{O}_{3}$ & None & $\begin{array}{l}\text { "active" oxygen } \\
\text { vacancies: } \\
\mathrm{In}_{2} \mathrm{O}_{3} \\
\rightarrow \mathrm{In}_{2} \mathrm{O}_{3-\mathrm{x}} \\
+\mathrm{e}^{-}[\mathrm{C} . \mathrm{B} .]_{2 \mathrm{x}}\end{array}$ & $1.03\left(\operatorname{In}^{3+}\right)$ \\
\hline $\begin{array}{l}\text { ICO } \\
(\mathrm{X})\end{array}$ & $\begin{array}{l}\mathrm{xCuO}+(1-\mathrm{x} / 2) \\
\mathrm{In}_{2} \mathrm{O}_{3} \\
(100 \mathrm{x}=0.1,0.5 \\
1,2.5,5)\end{array}$ & $\mathrm{Cu}^{+}$ & $\begin{array}{l}\mathrm{In}_{2} \mathrm{O}_{3-\mathrm{x}} \\
\rightarrow \mathrm{In}_{2} \mathrm{O}_{3-\mathrm{y}} \\
+[\mathrm{y}-\mathrm{x}] \mathrm{e}^{-}[\mathrm{C} . \mathrm{B} .]\end{array}$ & $-0.637\left(\mathrm{Cu}^{1+}\right)$ \\
\hline \multirow[t]{2}{*}{$\begin{array}{l}\text { IGO } \\
(\mathrm{X})\end{array}$} & \multirow{2}{*}{$\begin{array}{l}\mathrm{xGeO}_{2}+(1-\mathrm{x} / 2) \\
\mathrm{In}_{2} \mathrm{O}_{3} \\
(100 \mathrm{x}=2)\end{array}$} & \multirow[t]{2}{*}{$\mathrm{Ge}^{4+}$} & $\begin{array}{l}\mathrm{In}^{3+} \rightarrow \mathrm{Ge}^{4+} \\
+\mathrm{e}^{-}[\text {C.B. }]\end{array}$ & \multirow[t]{2}{*}{$3.06\left(\mathrm{Ge}^{4+}\right)$} \\
\hline & & & $\begin{array}{l}\mathrm{e}^{-}[\text {C.B.] from } \\
\text { "active" oxygen } \\
\text { vacancies }\end{array}$ & \\
\hline \multirow[t]{2}{*}{$\begin{array}{l}\text { IZO } \\
(\mathrm{X})\end{array}$} & \multirow{2}{*}{$\begin{array}{l}\mathrm{xZ \textrm {ZO } _ { 2 }}+(1-\mathrm{x} / 2) \\
\mathrm{In}_{2} \mathrm{O}_{3} \\
(100 \mathrm{x}=2)\end{array}$} & \multirow[t]{2}{*}{$\mathrm{Zr}^{4+}$} & $\begin{array}{l}\mathrm{In}^{3+} \rightarrow \mathrm{Zr}^{4+} \\
+\mathrm{e}^{-}[\text {C.B. }]\end{array}$ & \multirow[t]{2}{*}{$2.03\left(\mathrm{Zr}^{4+}\right)$} \\
\hline & & & idem & \\
\hline \multirow[t]{2}{*}{$\begin{array}{l}\text { ITiO } \\
(\mathrm{X})\end{array}$} & \multirow{2}{*}{$\begin{array}{l}\mathrm{xTiO} 2+(1-\mathrm{x} / 2) \\
\mathrm{In}_{2} \mathrm{O}_{3} \\
(100 \mathrm{x}=2)\end{array}$} & \multirow[t]{2}{*}{$\mathrm{Ti}^{4+}$} & $\begin{array}{l}\mathrm{In}^{3+}-\mathrm{Ti}^{4+} \\
+\mathrm{e}^{-}[\text {C.B. }]\end{array}$ & \multirow[t]{2}{*}{$3.06\left(\mathrm{Ti}^{4+}\right)$} \\
\hline & & & idem & \\
\hline \multirow[t]{2}{*}{$\begin{array}{l}\text { ITO } \\
(\mathrm{X})\end{array}$} & \multirow{2}{*}{$\begin{array}{l}\mathrm{xSnO}_{2} \\
+(1-\mathrm{x} / 2) \mathrm{In}_{2} \mathrm{O}_{3} \\
(100 \mathrm{x}=2)\end{array}$} & \multirow[t]{2}{*}{$\mathrm{Sn}^{4+}$} & $\begin{array}{c}\mathrm{In}^{3+} \rightarrow \mathrm{Sn}^{4+} \\
+\mathrm{e}^{-}[\text {C.B. }]\end{array}$ & \multirow[t]{2}{*}{$1.62\left(\mathrm{Sn}^{4+}\right)$} \\
\hline & & & idem & \\
\hline
\end{tabular}


mobilities versus carrier concentration, $\mathrm{n}$, are generally meaningful for polycrystalline ceramics of the same grain size and density. On the other hand, chemical homogeneity can be more difficult to achieve in single crystals.

The choice of these doping elements is based on the high value of the Lewis acid strength of $\mathrm{Ge}^{4+}, \mathrm{Zr}^{4+}$ and $\mathrm{Ti}^{4+}$ compared to that of $\mathrm{Sn} 4+[4-6]$.

\section{CERAMICS ELABORATION AND EXPERIMENTAL PROCEDURE}

All samples were prepared under similar conditions. Powders obtained by intimately mixing $0.3 \mathrm{~g}$ of the starting oxides (table I) were cold-pressed in a steel die and then isostatically pressed at 5 tons $/ \mathrm{cm}^{2}$. The pressed pallets were sintered in air at $1300{ }^{\circ} \mathrm{C}$ for $24 \mathrm{~h}$ after heating to temperature at $100{ }^{\circ} \mathrm{C} / \mathrm{h}$ : They were subsequently cooled at $100^{\circ} \mathrm{C} / \mathrm{h}$.

The structure and texture of the sintered samples were examined by X-ray powder diffraction and by electron microscopy respectively. For $\mathrm{Ti}, \mathrm{Zr}, \mathrm{Ge}$ and Sn doped IO ceramics, the grain sizes (average ca $1 \mu \mathrm{m}$ ) and densities (ca 0.72 theoretical) were all comparable to one another, and there was no evidence of second-phase formation at the grain boundaries for doping content of 1 atomic $\%$.

Accurate values of the conductivity $\sigma$, Hall mobility $\mu$, and carrier concentration $\mathrm{n}$, were obtained on polycrystalline plates typically $5 \times 5 \times 0.5 \mathrm{~mm}$ with an A.C. Van der Pauw four probes measurement of $\sigma$, a Hall measurement (in a $1.2 \mathrm{~T}$ magnetic field) of $\mathrm{n}$, and a calculated $\mu=\sigma /$ ne. An In-Ga eutectic was used to ensure ohmic contacts.

Optical absorbance measurement upon the same plate samples were investigated in the inter-band and free-carrier absorption regions (the corresponding wavelength is from $300 \mathrm{~nm}$ to $700 \mathrm{~nm}$ ).

\section{RESULTS AND DISCUSSIONS}

\section{I). Cu Doped IO and ITO Systems}

As shown in table II, the density of IO ceramics can be considerably increased by copper doping. This textured effect is in fact very similar to that observed for $\mathrm{Cu}$ doped $\mathrm{SnO}_{2}$ ceramics: the increase of grain size as the copper content increases accounts for the enhancement of density [3].

For 2.5 (atomic) \% Cu-doped IO samples, the density, equals to 7 (table II), is very close to that of single crystals. The average grain size is thus as large as 10 $\mu \mathrm{m}$. Unfortunately for this composition, there also exists the "impurity" phase $\mathrm{CuO}$, present at the grain boundaries.

From table II one deduces that the higher the sample density, the higher the mobility, and the lower the carrier concentration. The incrase in mobility has to be correlated to the increase in density but not to the decrease in the carrier concentration. Indeed for carrier concentrations of about $10^{18} \mathrm{~cm}^{-3}$ as it occurs 
TABLE II

Value of $\mathrm{Cu}$ doping concentrations in IO and ITO based ceramics; corresponding densities and values of the main electrical parameters.

\begin{tabular}{|c|c|c|c|c|c|}
\hline Starting material ratio & Sample & $\begin{array}{l}\text { Density } \\
\mathrm{g} / \mathrm{cm}^{3}\end{array}$ & $\begin{array}{l}\mu \\
\left(\mathrm{cm}^{2} v^{-1} \mathrm{~s}^{-1}\right)\end{array}$ & $\begin{array}{l}\mathrm{n} \\
\left(\mathrm{cm}^{-3}\right)\end{array}$ & $\begin{array}{l}\sigma \\
\left(\mathrm{cm}^{-1} \Omega^{-1}\right)\end{array}$ \\
\hline $\begin{array}{l}\mathrm{In}_{2} \mathrm{O}_{3} \text { single } \\
\text { cristal [7] }\end{array}$ & 0 & 7.1 & 160 & $10^{18}$ & 10 \\
\hline $\mathrm{Cu} / \mathrm{ln}=0$ & 1 & 4.9 & 28 & $2.5 \times 10^{18}$ & $1.12 \times 10$ \\
\hline $\mathrm{Cu} /(\mathrm{In}+\mathrm{Cu})=0.005$ & 2 & 5.0 & 40 & $2.0 \times 10^{18}$ & $1.28 \times 10$ \\
\hline $\mathrm{Cu} /(\mathrm{In}+\mathrm{Cu})=0.25$ & 3 & 6.0 & 55 & $1.7 \times 10^{18}$ & $1.50 \times 10$ \\
\hline $\mathrm{Cu} /(\mathrm{In}+\mathrm{Cu})=0.5$ & 4 & 6.2 & 65 & $1.5 \times 10^{18}$ & $1.56 \times 10$ \\
\hline $\mathrm{Cu} /(\mathrm{In}+\mathrm{Cu})=1.0$ & 5 & 6.5 & 80 & $1.2 \times 10^{18}$ & $1.54 \times 10$ \\
\hline $\mathrm{Cu} /(\mathrm{In}+\mathrm{Cu})=2.5$ & 6 & 7.0 & 90 & $0.8 \times 10^{18}$ & $1.2 \times 10$ \\
\hline $\begin{array}{l}\mathrm{Cu} /(\mathrm{In}+\mathrm{Sn}+\mathrm{Cu})=0 \\
\mathrm{Sn} /(\mathrm{In}+\mathrm{Sn}+\mathrm{Cu})=1\end{array}$ & 7 & 4.7 & 29 & $1.3 \times 10^{20}$ & $6.03 \times 10^{2}$ \\
\hline $\begin{array}{l}\mathrm{Cu} /(\mathrm{In}+\mathrm{Sn}+\mathrm{Cu})=0.25 \\
\mathrm{Sn} /(\mathrm{In}+\mathrm{Sn}+\mathrm{Cu})=1\end{array}$ & 8 & 4.9 & 33 & $1.5 \times 10^{20}$ & $7.92 \times 10^{2}$ \\
\hline $\begin{array}{l}\mathrm{Cu} /(\mathrm{In}+\mathrm{Sn}+\mathrm{Cu})=0.5 \\
\mathrm{Sn} /(\mathrm{In}+\mathrm{Sn}+\mathrm{Cu})=1\end{array}$ & 9 & 5.4 & 36 & $1.7 \times 10^{20}$ & $9.79 \times 10^{2}$ \\
\hline $\begin{array}{l}\mathrm{Cu} /(\mathrm{In}+\mathrm{Sn}+\mathrm{Cu})=1.25 \\
\mathrm{Sn} /(\mathrm{In}+\mathrm{Sn}+\mathrm{Cu})=1\end{array}$ & 10 & 5.7 & 37 & $1.8 \times 10^{20}$ & $1.07 \times 10^{3}$ \\
\hline $\begin{array}{l}\mathrm{Cu} /(\mathrm{In}+\mathrm{Sn}+\mathrm{Cu})=2.5 \\
\mathrm{Sn} /(\mathrm{In}+\mathrm{Sn}+\mathrm{Cu})=1\end{array}$ & 11 & 6.0 & 38 & $1.8 \times 10^{20}$ & $1.09 \times 10^{3}$ \\
\hline
\end{tabular}

here, the main scattering mechanism is due to acoustical phonons, and in this case, the mobility does not depend upon the carrier concentration [8]. However, the mobility always remains smaller than that observed for single crystals $\left(160 \mathrm{~cm}^{2}\right.$ $\mathrm{V}^{-1} \mathrm{~s}^{-1}$ ) [7], although the density is close to the theoretical value: The above mentioned "impurity" phase $\mathrm{CuO}$, present at the grain-boundary, probably introduces $\mathrm{Cu} 2+$-related recombination centers, which inhibits the "normally expected" in crease in the carrier mobility.

Finally, the decrease in the carrier concentration, deduced from Hall measurements, as the copper concentration increases, would imply that a small amount of copper enters as $\mathrm{Cu}(\mathrm{I})$ in the IO lattice, probably in a cationic substitutional position, so that one gets:

$\mathrm{IN}^{3+}+\mathrm{e}^{-}=\mathrm{Cu}^{+}$

For $\mathrm{Cu}$-doped ITO samples, the density is also increased by copper doping. However it remains smaller than that observed for $\mathrm{IO}: \mathrm{Cu}$; indeed it does not exceed 6 (table II). 
On the other hand, and most interestingly, the conductivity of ITO:Cu ceramics is enhanced by copper doping, since both the carrier concentration and the mobility increase as the density increases. In ITO, the free electrons mainly arise from the charge compensation:

$\mathrm{In}^{2+} \longrightarrow \mathrm{Sn}^{4+}+\mathrm{e}^{-}(\mathrm{CB})$

From the X-ray diffraction spectra analysis we have deduced that the presence of $\mathrm{CuO}$ enhances the solubility of tin oxide in indium oxide ceramics. Therefore, the increase in the carrier concentration with the copper content would mainly arise from the increase of tin solubility in $\mathrm{In}_{2} \mathrm{O}_{3}$. On the other hand, the effect of grain boundaries is weaker in the heavily doped semiconductors ITO: $\mathrm{Cu}\left(\mathrm{n}>10^{20}\right.$ $\mathrm{cm}^{-3}$ ) than in $\mathrm{IO}: \mathrm{Cu}$ as a consequence of the narrower depletion layer width at the interface between two grains. Consequently the increase of density with the copper content does not significantly affect the carrier mobility.

From the optical absorbance point of view, and as shown in fig. 1, the absorbance of IO: $\mathrm{Cu}$ samples is dominated by inter-band absorption at high energies; the deduced optical band-energy gap is of the order of $2.8 \mathrm{eV}$, a value which is currently obtained for ITO [1]. However for heavily doped ITO: $\mathrm{Cu}$ samples, the $\mathrm{Cu}$ doping induces an enlargement of the band-to-band transition as a consequence of the Burshtein shift effect [9]. For energies lower than that of inter-band transition, the absorbance is mainly due to the free-carrier absorption [10].

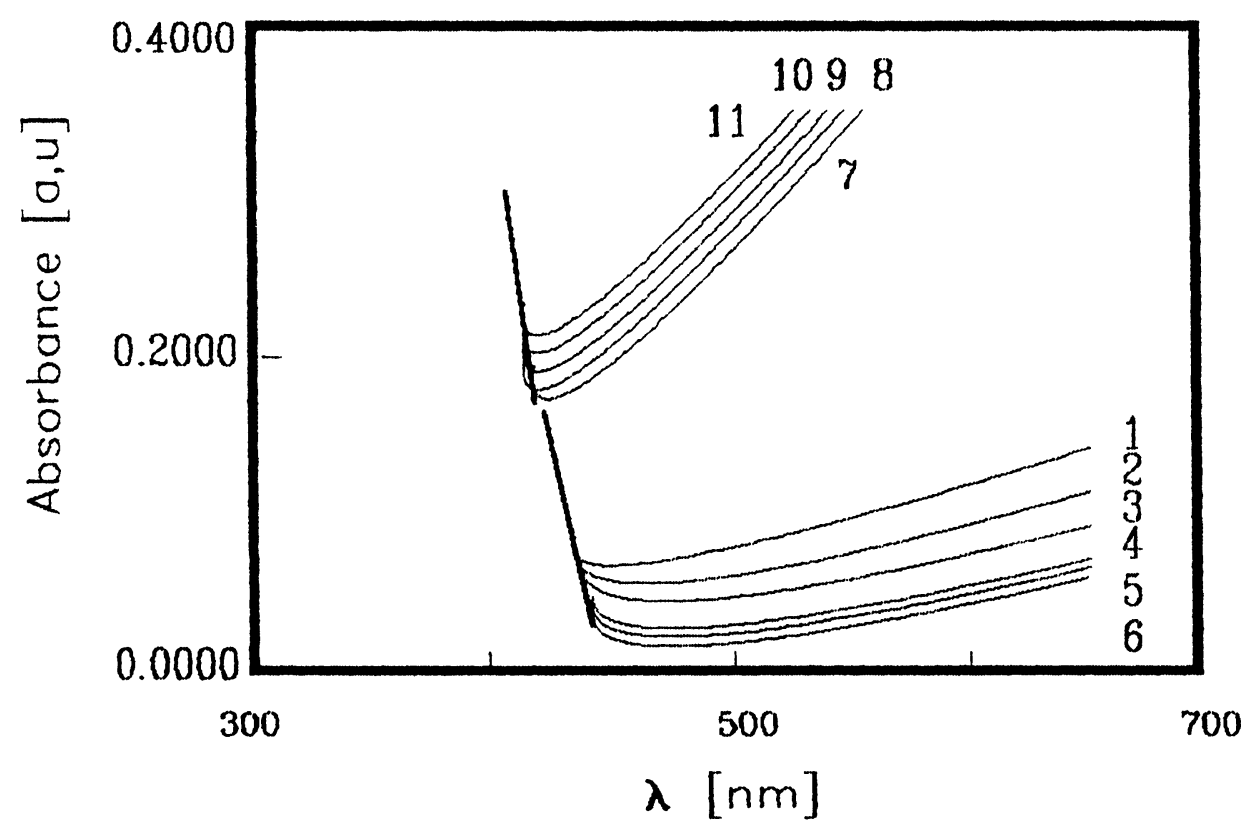

FIGURE 1 Absorbance versus the wavelength for various ceramic samples. The numbers alongside the curves have the same meaning as in table II. 
On the other hand, the free-carrier absorption varies with the energy more smoothly for IO and $\mathrm{Cu}$-doped IO than for ITO and $\mathrm{Cu}$-doped ITO because:

(i) in the former case, the scattering takes place mainly on the acoustical phonons as mentioned above; therefore the absorption coefficient $a$ varies with the photon frequency and is proportional to $v^{-1.5}$ [11].

(ii) in the later case, the scattering takes place mainly on the impurity ions; therefore the absorption coefficient is proportional to $v^{-3}[12]$.

\section{II). Ti, Zr and Ge doped IO and ITO systems}

For sake of an accurate comparation study we have chosen, for all samples, the same doping concentration, equal to 1 (atomic) \%. A decrease in lattice parameters consistent with the smaller size of the dopant $\left(\mathrm{Ti}^{4+}, \mathrm{Zr}^{4+}\right.$ and $\left.\mathrm{Ge}^{4+}\right)$ relative to $\mathrm{In}^{3+}$ and $\mathrm{Sn}^{4+}$ is observed.

Fig. 2 gives, for undoped and $\mathrm{Ti}$; $\mathrm{Zr}$; Ge-, or Sn-doped IO samples with nominal $\mathrm{x}=0.01$ (table I), the evolution of the room temperature Hall-carrier mobility and carrier concentration as a function of the doping element. Of particular interest

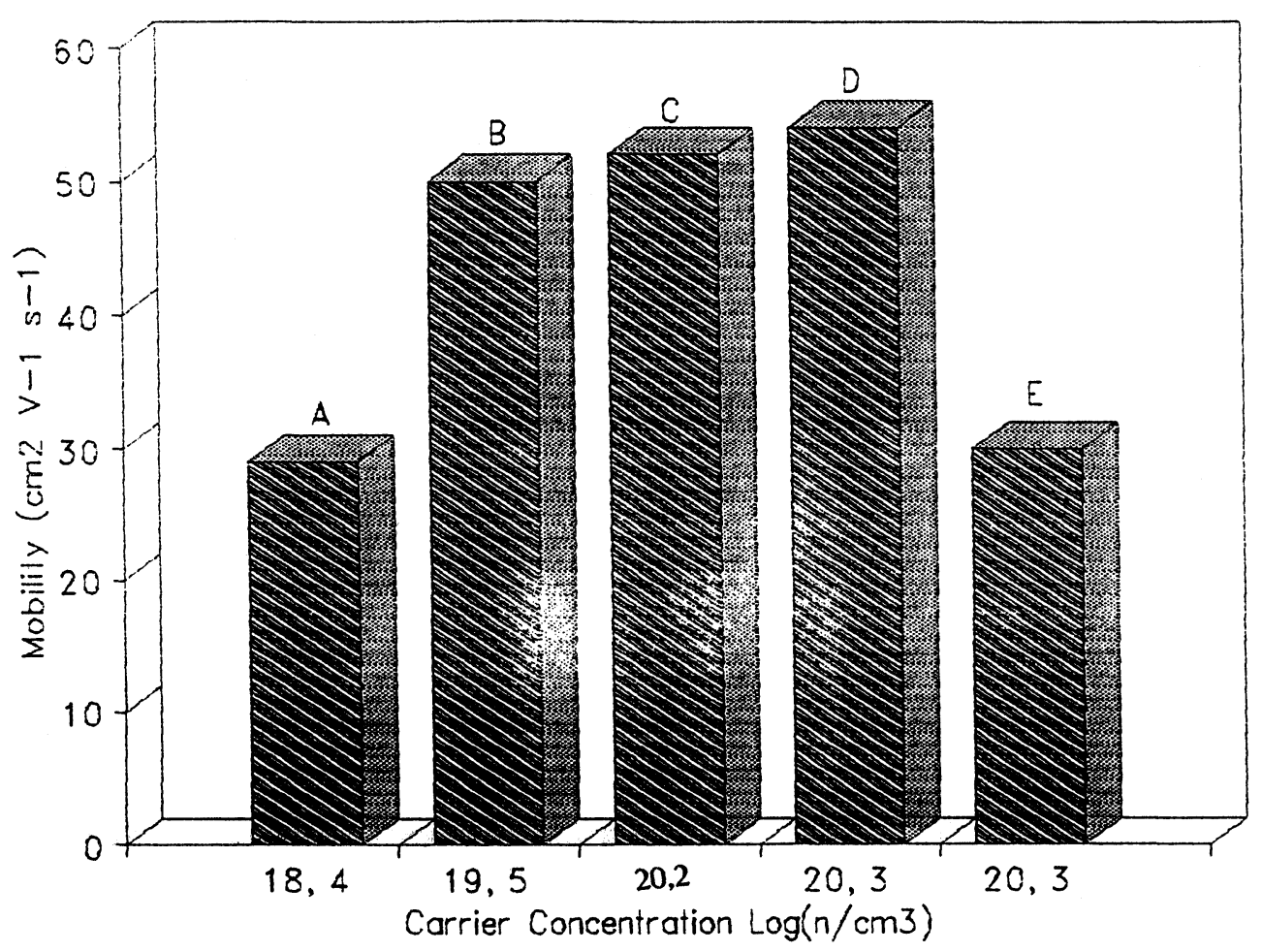

FIGURE 2 Evolution of the room temperature carrier mobility and carrier concentration as a function of the doping elements.

$\mathrm{A}=\mathrm{IO}, \mathrm{B}=\mathrm{IZO}, \mathrm{C}=\mathrm{ITiO}, \mathrm{D}=\mathrm{IGO}, \mathrm{E}=\mathrm{ITO}$.

For all samples: $\mathrm{M} /(\mathrm{In}+\mathrm{M})=0.01$, and here $\mathrm{M}$ is $\mathrm{Ti}, \mathrm{Zr}, \mathrm{Ge}$ and $\mathrm{Sn}$. 
is the enhanced Hall mobility in $\mathrm{Ti}-, \mathrm{Zr}$-, and Ge-doped IO samples compared to that of IO and ITO. We know that in heavily doped n-type semiconductors as it occurs here, the mobility is primarily limited by the scattering of electrons from ionized donor centers. For Ge-doped IO we have previously shown that such scattering would be reduced if the "Lewis-acid strength" of the donor element is higher than that of $\mathrm{In}^{3+}$ in IO based semiconductors. A more acidic ionized donor element such as $\mathrm{Ge}^{4+}$ would polarize the electronic charge from the $\mathrm{O}^{2-}: 2 \mathrm{p}^{6}$ valence band more strongly towards itself, thereby screening its charge so as to weaken it as a scattering center; consequently the carrier mobility in Ge doped IO is particularly high (fig. 2) [4].

Similar arguments obviously apply for $\mathrm{Ti}$ - and $\mathrm{Zr}$-doped IO, since from table I one notices that not only $\mathrm{Ge}^{4+}$ but also $\mathrm{Ti}^{4+}$ and $\mathrm{Zr}^{4+}$ have particularly high "Lewisacid strength" values.

Finally, and most interestingly, fig. 3 shows the increase in carrier mobility when the "conventional" ITO $(\mathrm{Sn} /(\mathrm{In}+\mathrm{Sn})=0.01)$ is doped by $\mathrm{Ti}, \mathrm{Zr}$ or Ge. These

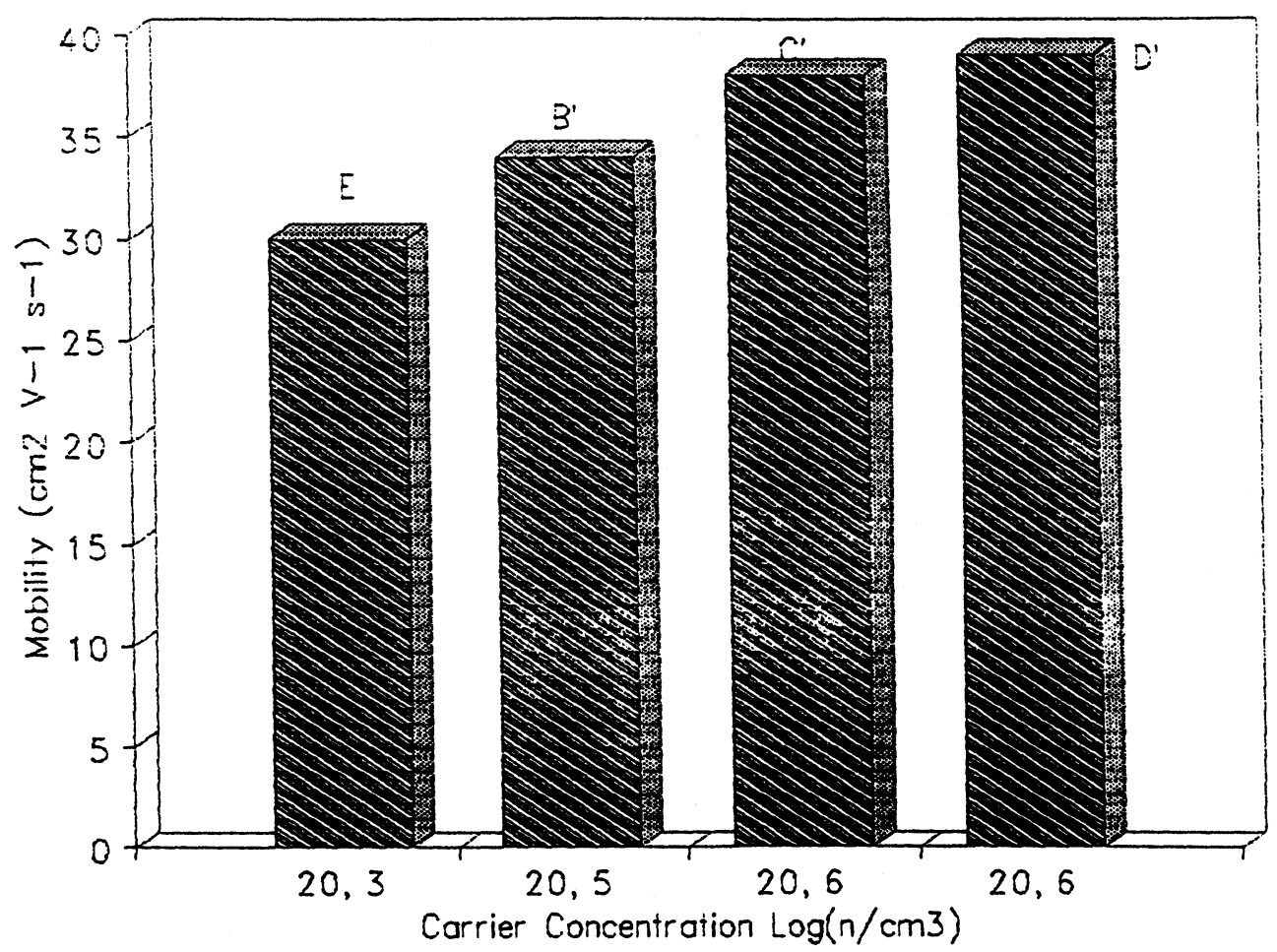

FIGURE 3 Evolution of the room temperature mobility and carrier concentrattion as a function of the doping elements.

$\mathrm{B}^{\prime}=\mathrm{ITZO}$ (starting materials: $\left.\mathrm{Sn} /(\mathrm{In}+\mathrm{Sn}+\mathrm{Zr})=0.01, \mathrm{Zr} /(\mathrm{In}+\mathrm{Sn}+\mathrm{Zr})=0.01\right)$.

$\mathrm{C}^{\prime}=$ ITTO (starting materials: $\left.\mathrm{Sn} /(\mathrm{In}+\mathrm{Sn}+\mathrm{Ti})=0.01, \mathrm{Ti} /(\mathrm{In}+\mathrm{Sn}+\mathrm{Ti})=0.01\right)$.

$\mathrm{D}^{\prime}=\mathrm{ITGO}$ (starting materials: $\left.\mathrm{Sn} /(\mathrm{In}+\mathrm{Sn}+\mathrm{Ge})=0.01, \mathrm{Ge} /(\mathrm{In}+\mathrm{Sn}+\mathrm{Ge})=0.01\right)$.

$\mathrm{E}=\mathrm{ITO}$ which has the same meaning as in fig. 2 .

The samples symbolization is chosen to be consistent with that of Fig. 2 . 


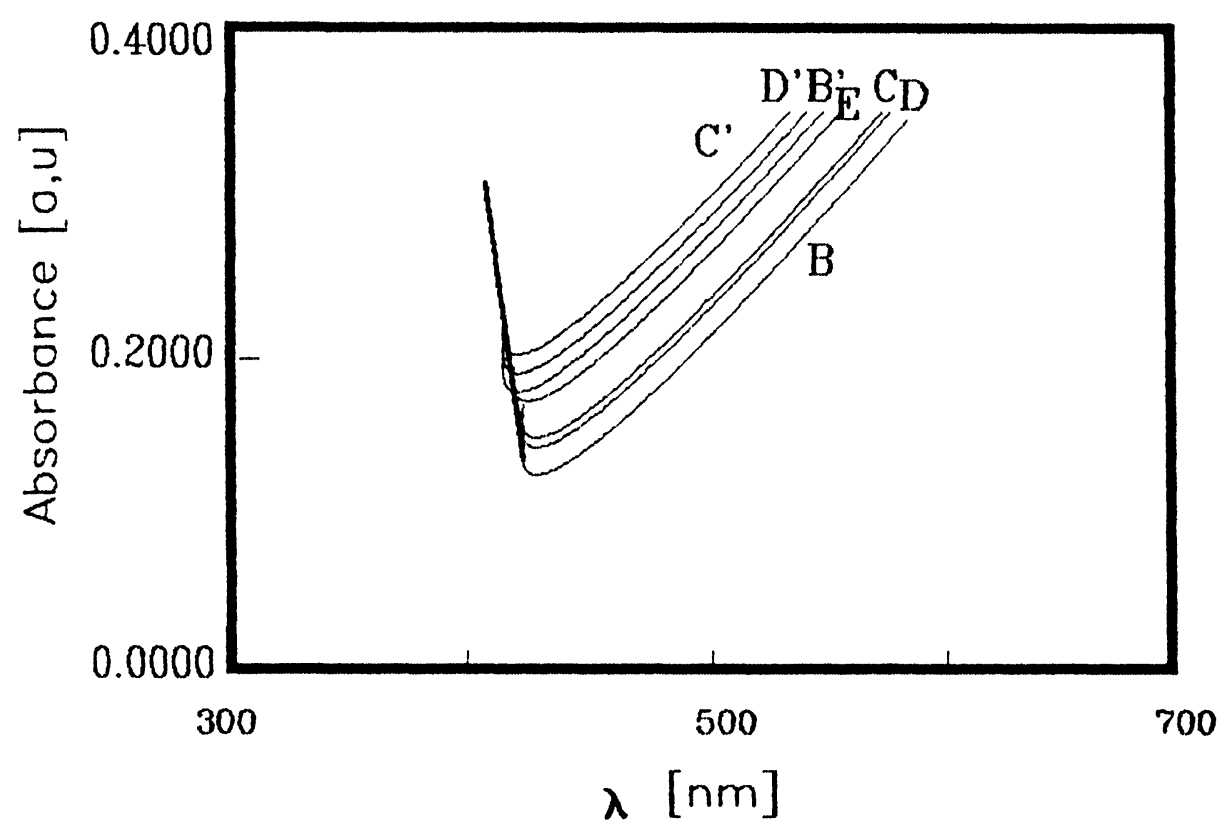

FIGURE 4 Absorbance versus the wavelength for various ceramics. The letters alonside the curves have the same meanings as in fig. 2 and fig. 3.

significant results can obviously be justified on the basis of our above reported arguments.

Fig. 4 gives the optical absorbance of the samples in the inter-band and freecarrier absorption region: the absorbance of $\mathrm{Ti}-, \mathrm{Zr}-$, and $\mathrm{Ge}$-doped $\mathrm{IO}$ is lower than that of ITO. It means that the Ti-, $\mathrm{Zr}-$, and Ge-doped IO samples in thin film form will be more transparent in the visible than "conventional" ITO films.

\section{CONCLUSION}

The electrical and optical properties of IO and ITO can be improved by doping with:

(i) $\mathrm{Cu}$, which modifies the texture by enhancing the density;

(ii) $\mathrm{Ti}, \mathrm{Zr}$ or Ge because the interactions between the conduction-band electrons and the ionized donor elements are minimized.

In particular, the charge carrier mobility in $\operatorname{In}_{2-x} \mathrm{M}_{\mathrm{x}} \mathrm{O}_{3}(\mathrm{M}=\mathrm{Cu}, \mathrm{Ti}, \mathrm{Zr}, \mathrm{Ge})$ is much higher than that of $\operatorname{In}_{2} \mathrm{O}_{3}$ and of $\operatorname{In}_{2-\mathrm{x}} \mathrm{Sn}_{\mathrm{x}} \mathrm{O}_{3}$ for $\mathrm{x}=0.01$. Besides, both the charge carrier mobility and carrier concentration in $\operatorname{In}_{2-x-y} M_{x} \operatorname{Sn}_{y} O_{3}(M=C u$, $\mathrm{Ti}, \mathrm{Zr}, \mathrm{Ge}$ ) are higher than those of $\mathrm{In}_{2-\mathrm{y}} \mathrm{Sn}_{\mathrm{y}} \mathrm{O}_{3}$ for $\mathrm{x}=\mathrm{y}=0.01$. Finally the Ti-, $\mathrm{Zr}$-, and Ge-doped IO and ITO ceramics are more transparent in the visible than IO and ITO. 
Consequently, ITO:Cu, ITO:Ti, ITO:Zr and ITO:Ge would be very good candidates to replace classical ITO. These thin films are presently under investigation.

\section{ACKNOWLEDGMENT}

The authors are grateful to A. Garcia and G. Couturier for very helpful technical assistance.

\section{REFERENCES}

1. J. Kane and H.P. Sheweizer, Thin Solid Folms, 29, 155 (1969).

2. K.L. Chopra, S. Major, and D.K. Pandya, Thin Solid Films, 102, 1 (1983) and references therein.

3. N. Dolet and J.P. Bonnet, J. Eur. Ceram. Soc., (Submitted 1992).

4. S.J. Wen, G. Campet, J.B. Goodenough, G. Couturier, and J. Portier, Mat. Sci. and Eng. (B), accepted in April 1992.

5. S.J. Wen and G. Campet, J. Act. Pass. El. Comp. (Submitted).

6. Y. Zhang, Inorg. Chem., 21, 3386 (1982).

7. J. Szczyrbowski, K. Schmalzbauer, and H. Hoffmann, Thin Solid Films, 137, 169 (1986).

8. R.L. Weiher, J. Appl. Phys., 33, 2834 (1962).

9. E. Burstein, Phys. Rev., 93, 632 (1954).

10. V.I. Fistul, "Heavily Doped Semiconductors", P. 208, Plenum Press, New York, Editor, Physical Semiconductor, (1968).

11. V.A. Yakovlev, FTT, 2, 1624 (1960).

12. H.J.G. Meyer, Phys. Rev., 120, 376 (1960). 

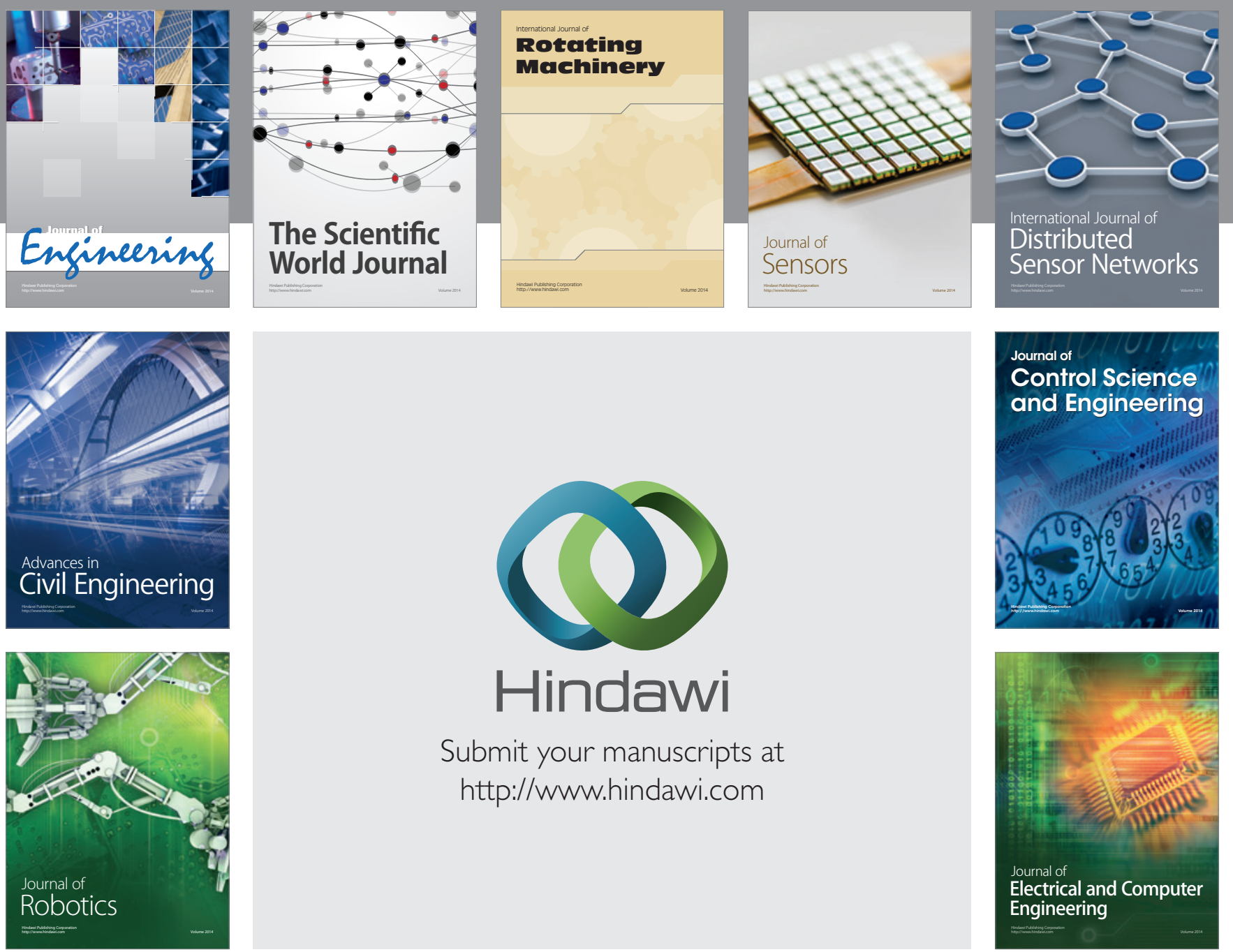

Submit your manuscripts at

http://www.hindawi.com
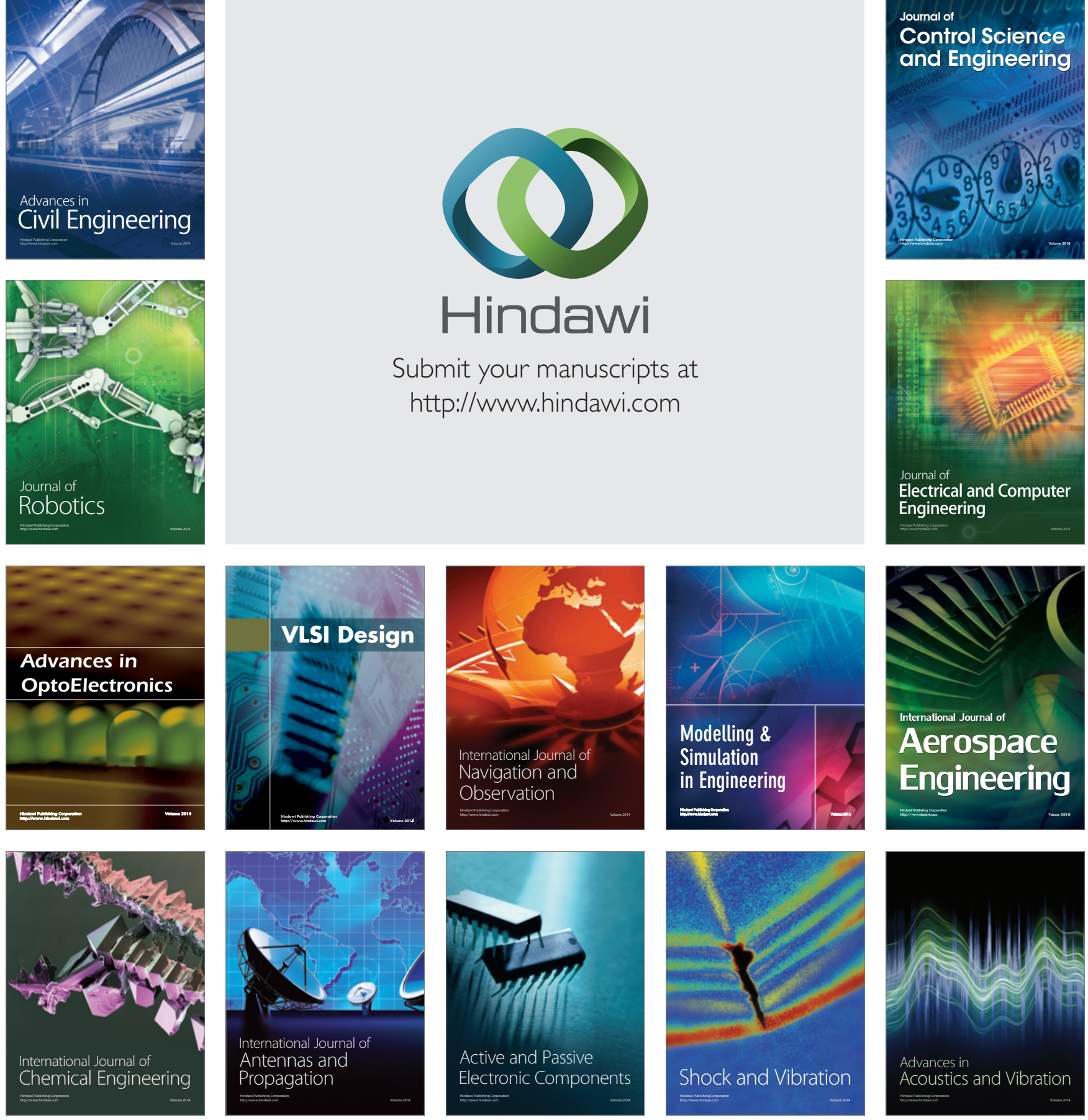